\title{
Lactobacillus reuteri Probiotic Tablet
}

\author{
National Cancer Institute
}

\section{Source}

National Cancer Institute. Lactobacillus reuteri Probiotic Tablet. NCI Thesaurus. Code C148148.

A tablet containing a strain of the probiotic Gram-positive, naturally-occurring bacterium Lactobacillus reuteri (L. reuteri), with potential antimicrobial, immunomodulatory and protective activities. Upon oral administration of the L. reuteri probiotic tablet, the Lactobacillus strain may improve digestion and help maintain adequate colonization of the gastrointestinal $(\mathrm{Gl})$ tract by modulating the composition of the normal microflora. During colonization of the Gl tract, this bacterium adheres to human intestinal epithelial cells, and activates intestinal epithelial proliferation; both of these processes promote the formation and maintenance of a protective barrier, thereby preventing the attachment of harmful pathogens. L. reuteri produces lactic acid and other substances during fermentation, and creates an acidic environment that is unfavorable for pathogens, thereby further protecting the intestinal mucosa against pathogen-induced damage and loss of integrity of the intestinal mucosal barrier. Dietary supplementation with this bacterium has been shown to decrease intestinal inflammation and enhance innate and acquired immunity. Lactobacillus reuteri is naturally found in the Gl tract. 